\title{
DO ESTADO DA UNIVERSIDADE: METIDA NUM SARCÓFAGO OU NO LEITO DE PROCRUSTES?
}

\author{
Jorge Olímpio Bento
}

Recebido: 16 jun. 2014

Aprovado: 31 jul. 2014

* Faculdade de Desporto da Universidade do Porto. Porto, Portugal. E-mail: jbento@fade.up.pt

Resumo: Este ensaio chama a atenção para a grave doença que atingiu a Universidade nos nossos dias. O recurso à metáfora do 'sarcófago' e do 'Leito de Procrustes' visa: acentuar o facto de que a Universidade está a abandonar a sua missão tradicional e a sofrer transformações perigosas; expressar a esperança de que ela se liberte das forças que a constrangem e consiga ressuscitar numa forma nova. Com efeito, a Universidade está sendo capturada pela ideologia, pelo pensamento, pela terminologia e pelos interesses do neoliberalismo e do mercado. Consequentemente, ela perde autonomia e voz e deixa de ter identidade, linguagem e pensamento próprios. Em vez de ser uma instituição ao serviço da Humanidade, da sociedade, da cultura, da democracia e da liberdade, a Universidade torna-se um fator e instrumento de propagação das doutrinas e receitas dos potentados financeiros e 'mercadológicos'. Tudo isto é bem visível no 'reformismo' e nas orientações da sua reorganização e governação, na oferta e no perfil dos seus cursos. Tal como o mercado, a Universidade já não oferece nada; só vende. Assim, a Universidade é cúmplice e corresponsável pela crise civilizacional, cultural, ética, moral e social que grassa no mundo. Em conclusão, a Universidade está a tornar-se uma instituição humana e socialmente irrelevante, sem capacidade de irradiar influências exemplares e positivas. Para reverter a situação, os protagonistas da Universidade têm que a tirar do 'sarcófago' ou do 'Leito de Procrustes', no qual, por ação ou omissão, a deixaram aprisionar.

Palavras-chave: Universidade. Neoliberalismo. Mercado. Crise de identidade. Necessidade de renovação.

\author{
THE STATE OF THE UNIVERSITY: HELD IN \\ A SARCOPHAGUS OR IN THE BED OF PROCRUSTES?
}

Abstract: This essay calls our attention to the serious disease that has affected University nowadays. The 'sarcophagus' metaphor as well as the 'Bed of Procrustes' fulfils the purpose of: emphasize the fact that University is forsaking its traditional mission and suffering dangerous transformations; hope for University sets free from all its constrained forces, by allowing a new rebirth. University is being captured by ideology, by reason, by terminology and by neoliberalism and market interests. Consequently, it is losing autonomy and voice and has no longer identity, language and own thinking. Instead of being an institution that works for Humanity, society, culture, democracy and liberty, University is becoming a factor and an instrument for spreading the financial and 'mercantile' rulers' doctrines and revenues. As a piece of evidence this can be seen through the 'reformism' and guidelines on University's reorganization and management, on offers and courses profile. As markets, University no longer offers only sells. Thus, University joins and shares responsibility upon the civilizational, cultural, ethical, moral and social crisis that is spreading throughout the world. University is becoming a human and social irrelevant institution, without the capacity to transmit archetypal and positive influences. In order to reverse the situation, the University's main leading characters must take it off from the 'sarcophagus' or from the 'Bed of Procrustes', where, by action or omission, have held it captive.

Key words: University. Neoliberalism. Market. Identity crisis. Need to reform. 
Contemporâneos passivos de uma civilização técnica e industrial, que nos serve o necessário poluído e o supérfluo esterilizado, já nem sequer nos indignamos de a ver acabar assim, pletórica e podre. Sornamente vamos vegetando intoxicados, na esperança secreta de que no dilúvio que acontecerá na nossa vida, se acontecer, haverá sempre na Arca de salvação lugar para mais um (Miguel Torga (1907-1995), Diário XVI).

\section{INTRODUÇÃO}

A figura do intelectual, que estruturou todo o século XX, desapareceu do debate público. Ainda que alguns assinem manifestos e participem em polémicas, o certo é que a sua repercussão na sociedade é mínima. Conscientes desta situação, muitos optaram pelo silêncio (Mário Vargas Llosa. A Civilização do Espetáculo).

Cada acontecimento ou situação contém e suscita uma pluralidade de leituras e de interpretações, não raras vezes com teor e sentidos antagónicos. No caso da presente tentativa de configuração, conformação e domesticação ideológica da Universidade, por controlos que ela não controla, sucede o mesmo; estamos perante um quadro que encerra uma diversidade de alegorias e percepções, de consequências e implicações.

Entre elas surge-me a intrigante metáfora do sarcófago, podendo também ser invocada, com todo o propósito e justificação, a do Leito de Procrustes. ${ }^{1}$

Cinjo-me particularmente à primeira, mas peço ao leitor que não despreze a segunda. Assim vou olhar para a Universidade, como quem contempla um sarcófago, partindo de alguns pretextos subjetivamente deveras significativos e incomodativos, suscetíveis de despertarem a sensibilidade para a gravidade da conjuntura. Ou seja, vou tentar entrar no sarcófago por distintas portas, confessando que não estou ciente de qual seria a ordenação mais plausível. Todas elas me assustam e levam a olhar e examinar um corpo em decomposição, abandonado por um espírito apoquentado, em errância e incerta peregrinação.

1 Como se sabe, segundo a mitologia grega, Procrustes ou Procusto, filho de Poseidon, tinha uma casa à beira da estrada sagrada, que ligava Atenas a Eleusis, na qual existia um leito especial. Os viajantes eram convidados para um merecido descanso e, mal adormeciam nessa cama, se as suas pernas fossem mais compridas do que ela, Procrustes cortava-as à medida do leito. Se fossem mais curtas do que o leito, seriam esticadas por um sistema de roldanas, até terem exactamente o mesmo tamanho da cama. Creio que é numa cama semelhante que as forças neoliberais tentam deitar a Universidade hodierna. 
Com o recurso à metáfora do sarcófago para caraterizar as vielas apertadas, onde está sendo metida a Universidade dos nossos dias, estou ciente de que me inscrevo na ordem de um pessimismo com sabor a tragédia, temperado pela esperança no acordar cristão. Sei que forço a barra, mas não o faço sem fundamento. Por um lado, a tragédia é uma das costelas constituintes da cultura que os helenos nos legaram. Por outro lado, estamos a assistir, afirma Michel Serres, ao 'assassinato do gosto europeu'. E por quê?

A peculiaridade da sociedade dita ocidental decorre do fato de que ela se constrói, simultaneamente, sobre o desaparecimento e a preservação da antiga civilização que ela nega [...] Se essas duas condições de nossas artes exemplares e de nossas excelentes condutas forem esquecidas, em dias futuros estaremos dançando diante das catedrais como os macacos que tagarelam diante dos templos de Yucatán e Angkor já invadidos pela floresta (SERES, 2003, p. 11-12).

Ora, na minha apreciação, a Universidade hodierna já foi atingida por esta mazela. Melhor dizendo, está sendo forçada a vergar-se a esta calamidade trágica: a ter que mudar e 'reformar-se', sem lhe ser consentido manter e conservar os seus pilares matriciais. Essa é a sua tragédia; e ela será tanto maior, se não souber entender o que se está a passar, aquilo a que está a aderir, a autonomia que está perdendo ou deitando fora e se capitular ou se demitir de resistir às forças e interesses ardilosos e poderosos de ocupação, perversão e usurpação do seu campus, da sua visão e do seu papel humanizador e social, da sua missão e esfera de intervenção.

O sarcófago traz-nos à lembrança a ideia da morte, da conservação tentada e da decomposição mitigada de um corpo, tomando este numa aceção lata e simbólica. Ora isto inclui, entre outras coisas, a erosão da espiritualidade e transcendência, da cultura e da norma ditas 'alta' e erudita, às mãos da 'civilização do espetáculo', assinalada e descrita minuciosamente por Mário Vargas Llosa. Igualmente inclui a crise da Europa, exemplarmente exposta e representada pela abdicação ou renúncia do Papa Bento XVI, eximiamente calculada e anunciada a 11 e mediaticamente realizada a 28 de fevereiro de $2013 .^{2}$

2 "A Europa vai entrar num declínio sob todos os aspetos - económico, cultural, intelectual. Aliás, a evolução das universidades na Europa é aterradora. Não na parte das ciências exatas, mas no que era o chamado 'ramo das humanidades' — e que infelizmente se passou a chamar 'ciências sociais' — as universidades entraram numa decadência aflitiva. A universidade pública tem desprezado esse ramo do saber. Como é que se alimenta cultura e os valores da cultura, se se nega pertinência, validade e interesse àquilo que são saberes não científicos, mas que são saberes à mesma? Então a Guerra e Paz do Tolstoi, O Vermelho e o Negro do Stendhal, o D. Quixote do Cervantes, um trio do Schubert, a Filosofia, não interessam para nada? Todo este ramo do saber está descuidado e pervertido pelos estudos culturais e pelo 
A presente decadência política, cultural e espiritual da Europa, da Igreja Católica e, no fundo, do modo de vida ocidental, é sobretudo uma agonia de natureza ética e metafísica. Tanto a renúncia do Papa como os rumos da política europeia, pesando em tudo o incontinente crescendo de abusos, imoralidades, mudanças, 'liberdades' ou permissividades e de acentuação da regressão nos deveres e direitos, são traços fortes e reveladores da crise geral de sentido, vivida pela civilização ocidental. Esta parece não saber mais o que é ou o que quer; não logra conceber a utopia sagrada ou profana que a atrai e põe em andamento. Ao invés, alastra uma amarga desertificação do transcendente e sagrado, vendo-se ambos perversamente convertidos em espetáculo.

Paradoxalmente, qualquer mortal comum se apercebe da escuridão, da noite e das epidemias que invadiram este mundo; e de que somente será possível salvá-lo descendo silenciosamente à cripta onde repousa o túmulo daquilo que foi sepultado e de que temos nostalgia, abrindo-o e esperando uma profética ressurreição.

Sem a recusa de um mundo que, ao empobrecer o presente, renuncia ao futuro, sem abandonar o culto idólatra dos deuses menores que nesta era se impõem com estatuto maior, a esperança ocidental, matricialmente gerada e nutrida pelo cristianismo, não terá concretização. Por outras palavras, temos que nos abeirar do sarcófago, porque somente os túmulos conhecem a redenção e ressurreição.

De resto, é a ideia da ressurreição, um sólido pilar judaico-cristão, fundador da cultura ocidental juntamente com o agonismo, a tragédia e a transcendência gregas, que nos aproxima do sarcófago numa tentativa de perpétua busca do nosso Ser, do que perfaz a sua virtualidade e eternidade.

A relação entre o material e o imaterial dá-se através de uma convivência contraditória e conflituante entre o visível e o oculto. Parte-se do tempo breve e reflexivo para descobrir no mesmo a essência do seu prolongamento, para um tempo cosmológico que não tem meta.

Logo, "como as fontes do Espírito nunca secam, todas as viragens são possíveis", no dizer de Frei Bento Domingues (2013, p. 53), pode ser que consigamos reverter a situação em que se encontra a Universidade.

pós-modernismo. Daqui vem uma ameaça à sanidade cultural do pensamento do Ocidente. [...] Há uma relação entre pósmodernismo e neoliberalismo. O neoliberalismo corrói e opõe-se à social-democracia e à democracia cristã. O pós-modernismo é a outra lei da selva, é a lei da selva no campo cultural e intelectual. Não é por acaso que surgem, alastram e invadem ao mesmo tempo. Eu sou muito conservadora, mas não subscrevo, nem nunca subscreveria, a tese de que a vida em sociedade está sujeita à lei da seleção natural dos mais fortes e que os mais fracos podem rebentar contra a parede." (Maria de Fátima Bonifácio, jornal Público, 11.03.2012). 


\section{A UNIVERSIDADE COMO INSTITUIÇÃO DA CIVILIZAÇÃO}

Sei que seria possível construir a forma justa / De uma cidade humana que fosse / Fiel à perfeição do universo. (Sophia de Mello Breyner Andresen (1919-2004). A Forma Justa).

I

Desde os primórdios da civilização, a sabedoria humana tem consistido em estabelecer a prevalência do espiritual, moral e sagrado sobre o material, animalesco, mundano e profano e em criar instituições que encarnam, difundem e consolidam essa primazia.

Nessas instituições repousa a incumbência de indicar as metas e sentidos do processo civilizacional, de fornecer as referências, energias e reservas que animam os nossos passos, as pernas que permitem avançar, os braços que ajudam a subir, os olhos que possibilitam discernir, os ideais que permitem sorrir. Elas concebem as artes, os instrumentos e os métodos que nos facultam e intimam a tornar possível o impossível, próximo o distante, realizável o idealizável, factual o virtual, familiar o estranho, a perseguir o infinito e a apresentar mais compreensíveis, leves, palpáveis e tangíveis os trágicos, profundos e indecifráveis mistérios da vida.

A história da Humanidade é contada e interpretada pelo papel e trajeto das suas instituições ao longo dos tempos, pela sobrevivência e transformação de algumas, pelo desaparecimento e substituição da maioria delas, em sintonia com os arcanos, anseios, contradições e problemas de cada época. Elas são uma representação do entorno em que surgem os poetas e vates, os oráculos e profetas, os filósofos e pensadores e toda a sorte de artífices e pontífices que constroem e abatem mitos, causas, paradigmas, utopias e distopias, educam os povos e lançam pontes entre o passado, o presente e o futuro.

II

A Universidade inclui-se nesse escol de instituições e têm muito em comum: é um produto da Modernidade, do Humanismo e Iluminismo, recebe destes os pilares da sua fundação e missão. Isto é, a luz da filosofia e da cultura ilumina a Universidade com o fulgor dos axiomas gregos da perfectibilidade e da transcendência. ${ }^{3}$

3 A transcendência é a dimensão religiosa de toda a cultura. Dito de outro modo, a cultura é uma manifestação humana de índole religiosa, que exprime ou tenta exprimir o que, em nós, há de melhor: a busca da fonte de sentido, o que podemos esperar da vida e o que devemos fazer uns pelos outros da forma mais autêntica, mais bela, mais elevada e excelente possível. Por isso a cultura encerra uma axiologia, uma ética e uma estética. 
Almeja prosseguir a procura do Homem Novo, dono e senhor da natureza, um ser de liberdade e dos possíveis, inconcluso e inacabado, fora de escala e sem especificidade, essência natural e identidade a priori, fiado na logodiceia e descrente da teodiceia. Visa tornar os humanos sujeitos da sua vida, aptos a superar a inumanidade de que somos parte, sob a luz da razão, da ética e da estética, dar-lhes uma arquitetura e 'forma' interiores e exteriores, conformes às grandezas idealizadas.

Wilhelm von Humboldt (1767-1835) bebeu nessa fonte a inspiração para, na peugada de Giovanni Pico della Mirandola (1463-1494), de Voltaire (16941778), de Rousseau (1712-1778), de Kant (1724-1804), de Pestalozzi (17461827) e Goethe (1749-1832), entre tantos outros, apresentar as traves-mestras da Universidade Moderna e coligir os elementos do conceito de 'Formação' (Bildung).

A palavra-chave sobre a instituição universitária, de que Humboldt se socorreu, ao fundar a Universidade de Berlim em 1810, foi 'ideia', a 'ideia de universidade'. Ela tinha afinidade com a 'arété' dos helenos, recuperava e remia a sua essência axiológica; consubstanciava o processo de busca ilimitada e incondicionada de aperfeiçoamento, formação e conhecimento, um programa utópico nascido do Iluminismo.

Requer-se aqui um esclarecimento a propósito da noção de 'arété', uma expressão abrangente e ampla, inventada pelos pensadores gregos, que congregava a unidade harmoniosa de muitas dimensões. Ela continha e contém indicadores do grau de humanidade dos humanos; intimava-os ao esforço de perseguir o aprimoramento e a perfectibilidade, visando torná-los 'quase perfeitos, 'quase felizes, 'quase divinos'. Por outras palavras, os humanos eram definidos como seres 'artísticos'; o grau da sua humanidade dependia do teor da 'arété' (técnica, ética, estética, magnificência, excelsitude e virtude) incorporada e demonstrada no corpo e na alma, nas aptidões e expressões, nas emoções e reações, nos gostos e inclinações, nos sentimentos e comportamentos, nos atos e palavras, nas atitudes, condutas e posturas.

Os clássicos do Humanismo e Iluminismo recuperaram e atualizaram o conceito; e este chegou até aos nossos dias, pleno de fulgor para o empreendimento da educação, não tendo encontrado um substituto à altura, tão empolgante e mobilizador.

Mas... hoje no dicionário e no vocabulário corrente da Universidade entrou o termo 'excelência'. O que é que ele quer dizer? Será o mesmo que os gregos expressavam com o conceito de 'arété' e que Humboldt tomou em consideração, quando refundou a Universidade Moderna e formulou os ele- 
mentos constituintes do ideal filosófico e antropológico da 'Formação' ou 'Bildung'?

O referencial da 'ideia' e o que ela albergava foram destituídos pela palavra mágica 'excelência', que se foi impondo, nas últimas três décadas, primeiro nos EUA e depois na Europa. Os motivos são óbvios. Nela encontram eco as exigências de um Estado avaliativo, controlador, disciplinador, fiscalizador, humilhador, policial, punitivo e vexatório, que tudo quer medir e avaliar em termos de eficácia, eficiência e lucro, num jogo de soma zero em que só há vencedores e vencidos, ganhadores e perdedores, uma espécie de ideal eugenista visando apurar os excelentes, fortes e melhores e descartar e eliminar os bons, os medianos, fracos e piores. Consequentemente a burocracia apoderou-se das universidades e estas deixam-se, pouco a pouco, enlear pelos braços controladores e tentaculares de entidades e forças externas. Também por esta via, a Universidade entrou na noite, sem saber quando começa o dia.

Em suma, a Universidade provém da fonte matricial do Humanismo e Iluminismo. Temos que a revisitar, verificar e reparar a medida da sua insana afetação pela loucura da contemporaneidade, sopesar o abandono da mensagem original, sacrificada no altar do utilitarismo demencial.

Temos que fazer jus ao nosso nome: levantar-nos do chão, lamber as feridas como um 'cão de lágrimas', romper o cerco da cegueira com a luz dos sonhos, sobreviver numa jangada de pedra às forças da alienação e opressão, contrariar a propensão para elefante, libertar-nos da condenação e fado de Caim e subir no céu como morteiros impulsionados pela pólvora do espírito e ousadia, para escrevermos, com as letras e a tinta do compromisso e decência, um manual da existência e deixarmos de nós um memorial do impossível. ${ }^{4}$

\section{DA MODERNIDADE 'SÓLIDA' À CONTEMPORANEIDADE 'LÍQUIDA’}

M'espanto às vezes, outras m'avergonho. (Sá de Miranda, 14951558).

I

Tomo por convincente a análise de Zygmunt Bauman (2013) que carateriza a era atual como a 'fase líquida' da Modernidade, muito embora me pareça

4 Este parágrafo, percebe-se bem, constitui uma homenagem a José Saramago (1922-2010), porquanto é tecido com títulos de alguns dos livros da sua autoria. 
mais conforme a designação de outros autores quando classificam a contemporaneidade como 'pós-modernidade'.

Respaldado em ambas as interpretações, atrevo-me a encarar este nosso presente como um sarcófago da Modernidade sólida, que contém intenções, promessas, ideais, causas, aspirações, paradigmas e até dogmas condenados à decomposição ou, quiçá, aguardando a sua ressurreição numa nova versão.

Interrogo-me se haverá alguma esperança na ressurreição do corpo da Universidade, após ela já ter sido deitada no Leito de Procrustes ou Procusto e lhe terem sido serradas ou arrancadas as pernas da autonomia da sua caminhada. E o seu espírito em que forma reincarnará?

Parece-me curial olhar a situação hodierna da Universidade à luz desta perspetiva. Afirmemos, sem rodeios: a Universidade, cujos pilares basilares Humboldt delineou, é desde o seu berço uma entidade concebida no leito genuinamente 'sólido-moderno'. Esse leito já foi abandonado por outras entidades. Será que essa fundamentação da Universidade ainda consegue sobreviver nesta era líquida, na qual, parafraseando os velhos, barbudos e papões Marx e Engels, ocorre novamente (como noutras mudanças de época) o derretimento de tudo o que é sólido e a profanação de tudo o que é sagrado? Ainda detém algum potencial para recategorizar a existência humana e dar-lhe feições de obra de arte?

A Universidade era parte essencial do projeto da Modernidade e das suas estruturas sólidas, destinadas a substituir o caos e as circunstâncias então reconhecidas como frágeis, caprichosas e descontroladas, ultrapassadas e putrefactas, e a produzir, sob medida, um ambiente humano com contornos e efeitos mais confiáveis e fidedignos, racionais, ordenados e previsíveis, aperfeiçoados e duradoiros.

O projeto, inspirado em utopias, não olhava para si como algo acabado ou concluso, mas como uma trajetória longa e continuada, que almejava chegar a etapas bem assinaladas na marcha do 'progresso', com rumo direcionado para a consumação de um tipo superior de vida, de segurança, de equidade e dignidade dos humanos. No fundo, como refere Bauman (2013, p. 43), porventura reavivando Aristóteles (384 - 322 a. C.), "o propósito do movimento era chegar a um estado estável. O objetivo do esforço era o estado de descanso, o do trabalho duro, o lazer." 5

5 Repare-se na similitude com a posição de Aristóteles: "A guerra deve ser em vista da paz, a atividade em vista do ócio, as coisas necessárias e úteis em vista das coisas belas. É verdade que é preciso desempenhar uma atividade e combater, mas muito mais importante é estar em paz e em ócio, assim como é preciso fazer as coisas necessárias e úteis, mas mais importantes são as coisas belas." (MASI, 2000, p. 3) O Ócio Criativo. Neste livro só consta a primeira parte da citação; eu acrescentei-lhe a segunda fase, porque a aprendi assim na minha formação básica e a li e escutei em vários textos e conferências. 
A ideia do progresso tinha a ciência e a tecnologia como meios, e o avanço para uma sociedade de bem-estar universal e do ócio criativo como fim, sendo este último um desiderato muito antigo, inscrito como lei compulsória no terceiro dos mandamentos ordenados por Deus e proclamados e escritos pela boca e mão de Moisés. Não se tratava de eliminar a quantidade infinita de problemas de uma vez, mas de dar passos para ir deixando para trás, uma após outra, as barreiras dificultadoras da eliminação das necessidades que afligem os humanos e a sua convivência. No fundo a promessa moderna-sólida de ' $i$ berdade, igualdade e fraternidade' era assumida como ideal da democracia, quer pela visão capitalista, quer pela socialista.

A Universidade constituía neste contexto uma casa da erudição, da sabedoria, da cultura, da espiritualidade, do primado da verdade sobre a utilidade, dos 'inutensílios' sobre os utensílios, do imaterial e intangível sobre o material e tangível, enfim, uma sede do espírito livre.

II

Quando hoje prestamos atenção ao que se passa ao nosso lado e redor, ouvimos, com toda a nitidez, um arrepiante toque de finados e um coro de requiem, acompanhando o enterro e o ingresso ou depósito da modernidade no sarcófago da sua fase líquida.

Há competidores (p. ex., o capitalismo financeiro) que se retiraram da competição e mudaram de campo: da modernidade sólida passaram para um cenário líquido, visando não a satisfação, mas o crescimento infinito de desejos, a oferta multiplicada de miríficas oportunidades, sem estruturar a probabilidade de as garantir.

Isto intima-nos a perguntar: Terão chegado ao fim a Modernidade, as suas ambições, causas e utopias, os seus fins e ideais, assim como os seus instrumentos principais, entre os quais a Universidade? Significará isto a sua retirada irreversível e a sua morte derradeira? Ou estarão num estado de latência, a aguardar ansiosamente pela sua inevitável ressurreição?

Esta pergunta é acompanhada pela constatação de que a substituição da Modernidade 'sólida' pela contemporaneidade 'líquida' não traduz, como noutras transições de era, uma perceção de melhoria ou bem-aventurança, mas, ao invés, um avolumar do capital da ansiedade e insegurança. À nossa volta, se não formos cegos voluntários, vemos crescer e florescer, de forma horrenda e gritante, aspetos aviltantes, imorais, repugnantes e revoltantes da 
condição humana, como se estivéssemos condenados a uma inexorável regressão civilizacional e a atirar para a vala-comum os 'imperativos morais', estabelecidos por um sujeito deveras incómodo, chamado Kant.

Com efeito, a lista das aflições existenciais, dos 'males sociais' e dos 'danos colaterais' (crescendo da corrupção, rapacidade e busca do lucro rápido e indecoroso, dos índices de pobreza, da indiferença em relação ao outro, dos homicídios e suicídios, da mortalidade infantil, dos problemas emocionais e mentais, a queda de rendimentos, o declínio do julgamento ético nas relações humanas, do senso de partilha, de comunidade e solidariedade, a hipertrofia da subjetividade e do individualismo, a demissão e o lavar-as-mãos das autoridades face às várias formas de exclusão e marginalização consideradas um mal necessário, a exploração e manipulação dos medos, da insegurança e incerteza, as políticas e 'reformas' fundadas na falsidade e amoralidade gritantes, na indecência e maldade inescrupulosas, no dolo e no engano grosseiros, na humilhação e na tramoia ignominiosas das pessoas, etc.), por conta do obsceno aumento das desigualdades sociais, alonga-se em todo o mundo num ritmo alucinante; nenhuma sociedade fica de fora deste mapa de horrores, tampouco as ditas 'sociedades desenvolvidas'. Pior ainda, é legítima a suspeição de que não é genuíno o esforço para os evitar e remediar, perante a "redução dos suprimentos de ajuda mútua sem os quais a coesão e a cooperação sociais são inconcebíveis" (BAUMAN, 2013, p. 53).

As pessoas são tratadas como cães e formatadas para que um dia não venham a morder. Passados tantos séculos de civilização, a contemplação deste mundo provoca um choque brutal. Tornou-se imundo (não mundo); é uma chaga aberta, exala pus e inumanidade, um cheiro a podre que adentra as narinas desprevenidas e a consciência distraída. Fede mesmo, causando náuseas no estômago e sobretudo na alma.

\section{III}

$\mathrm{Na}$ cor triste da realidade e da incredulidade é bem visível a maior doença do presente: vivemos todos no mesmo tempo físico, mas a maioria dos humanos não acede à contemporaneidade no plano da fruição da técnica, do protagonismo social, cultural e político, bem como do exercício da indagação, do questionamento e do espanto. Pelo contrário, em todo o lado emerge a prova provada de quão alto e hediondo é o cume do inumano, gerado pela armadilha da globalização. E de que esta, longe de afirmar o poder de criação do homem, corre o risco de o instituir como sujeito da indiferença, da destruição e iniquidade. 
Vivemos uma hora trágica, uma hora dramática, uma hora civilizacional e eticamente crepuscular. Sobre as nossas cabeças pesa a exclamação dramática do Talmude babilónico: Mesmo uma voz do céu não prevalece sobre aquilo que existe!

Este quadro da fealdade, ignorante de que o Ser Humano só existe e se concretiza nos indivíduos humanos (em todos!) faz soar um alerta na nossa consciência, desafia a apatia ética e a quietude moral. Obriga a irromper de dentro de nós um vigoroso grito de denúncia da mentira e falsidade da globalização em financês e mercadês. De que é incontornável e urgente tornar universal e globalizar - isso sim! - o remedeio desta contemporaneidade. E legitima a esperança de que o Humanismo e muitos dos ideais e fautores da Modernidade 'sólida' possam ressuscitar, quiçá com outro corpo e linguagem.

Afinal, a promessa da 'vida boa', que deve ser procurada por cada um e resulta do tão exaltado e incensado culto da sacrossanta trilogia mercadológica da 'competitividade', 'empreendedorismo' e 'sucesso', continua por atingir. Ela não é possível como solução individual e isolada. A vida boa só é aceitável e realizável como humanamente boa, isto é, entre seres humanos; caso contrário, ainda poderá ser vida, mas não será 'boa' nem 'humana' (SAVATER, 1991, p. 53).

\section{IV}

Ora isto manda perguntar: Como se comporta e compromete a Universidade neste panorama? Em que estado e com que forma sairá ela do sarcófago ‘líquido’ em que se encontra a hibernar e penar? Está a cumprir a função atribuída pela Modernidade ou abdicou de ser Universidade e casa da liberdade, cometendo traição e rebaixando-se à configuração de mais um instrumento da campanha massiva do pensamento único, colocando-se ao serviço rígido do colaboracionismo com a orientação ideológica do mercado neoliberal, assumindo 'disfunções' neutralizadoras de inquietudes no tocante a 'lealdades' a interesses e entidades estranhas à sua matriz original? ${ }^{6}$

Contenta-se em ser, tomando emprestada a expressão de Max Weber (18641920), um tipo de fábrica de conduta racional, melhor dizendo, de fábrica de comportamento irracional, divorciada de dimensões emocionais e morais? (BAUMAN, 2013, p. 56).

6 "Não existem maus pensamentos, com exceção de um: a recusa em pensar" (Ayn Rand, 1905-1982, escritora, dramaturga, roteirista e filósofa norte-americana). 
Satisfaz-se com uma racionalidade desabitada da sensibilidade essencial, com o estilo super-racional de linguagens e modos de pensar esquecidos da necessidade de incluir as emoções nas avaliações e decisões? ${ }^{7}$

Concedamos que a saúde humanista da Universidade está muito mal. Mas pode ter cura, conquanto os seus protagonistas decidam tomar os remédios apropriados.

"Efémeros são os oiros dos biltres"- reza o primeiro verso do poema " $O$ mote de Camões”, do grande José Craveirinha (1922-2003). Passageiros e transitórios, sussurra a voz da esperança nesta conjuntura de desespero e perdição, são os peritos da demagogia e populismo, da alienação e manipulação que enriquecem rápida e exponencialmente, perante o aumento e silêncio da pobreza envergonhada. Contudo a esperança deve ser temperada pelo aviso de Platão (427-347 a.C.), ao afirmar que a ideia do bem é mais difícil de aprender e aplicar do que a ideia do mal. Afinal os princípios, valores, ideais, obrigações e mandamentos encontram melhor morada nos livros do que no coração, na vontade e determinação de agir dos homens. Caminhamos num rumo onde ser honesto será um defeito e não uma virtude.

Acordemos dos enganos, em que caímos com insana devoção. Não basta proclamar retas e boas intenções e falhar na escolha dos instrumentos e agentes das ações. Quem nas primeiras atina e nas segundas anda na contramão só aumenta braços ao problema e corta mãos à solução. Acordemos e clamemos por um tempo de claridade e renovação. A desdita do presente reza e suplica por urgente substituição.

\section{UM OLHAR SOBRE A PÓS-GRADUAÇÃO}

A roda do tempo, com o progresso acelerado que tudo altera, desandou e, no turbilhão, degradaram-se os valores. E é forçoso reconhecer e lamentar que, pelo que nos diz respeito, o que ganhamos em saber profissional perdemos em humanidade. (Miguel Torga, Diário $X V I)$.

7 Ao empregar aqui a expressão 'sensibilidade essencial', pretendo prestar o meu tributo de homenagem a Rubem Alves, falecido no dia 20.07.2014. A extraordinária relevância dos seus textos vai ser cada vez mais reconhecida, porquanto, desgraçadamente, estamos impondo às nossas crianças um arremedo de educação que lhes mata aquela axial dimensão. O falecimento de Rubem Alves deixa mais pobre o já tão empobrecido pensamento sobre a educação na atualidade. Cala-se mais uma voz da beleza poética e mais um ourives da leveza das palavras aladas. E tanto precisa delas a educação, esmagada como está pela ditadura do 'economês', 'financês' e 'utilitês'! Se a racionalidade de muitos políticos incluísse o sensível, ser-lhes-ia mais difícil tomar medidas que empurram as pessoas para o desvão da indignidade e desumanidade. 
Vivemos numa conjuntura em que as palavras não passam de ardis para impingir uma 'saída limpa' da estrumeira em que nos atolamos.

É curial afirmar e apontar estas coisas aqui e agora. O 'aqui' refere-se ao mundo e à Universidade; o 'agora' a esta hora crepuscular e à já aludida civilização do espetáculo, inimigas da reflexão, em que todos, com irresponsabilidade mais ou menos diluída, aceitamos participar.

É com dorida mágoa que me volto para a Universidade: edificada para ser casa da espiritualidade, para fomentar o 'espírito livre'.

O que é feito dessa instituição da Modernidade, cujos alicerces e alvos Humboldt tão luminosamente plantou? Mal a vemos, porque foi abatida com a nossa conivência e cumplicidade, por ação ou omissão. Quem a substitui? A resposta titubeia, porquanto a 'coragem', a virtude que Aristóteles considerou a mais importante de todas, não é abundante e saiu de moda; e a 'liberdade', o genuíno alimento dos Seres Humanos, tal como a ambrosia era o dos deuses, encontra-se perecível, num torpor de morbidez.

A Universidade hodierna afunda-se na capitulação. Faz de conta que não percebe o lembrete de Eduardo Lourenço (2014, p. 11-12): "A liberdade sem preço não é liberdade." Esta "é uma luta sem fim."

Ao não abjurar e verberar a descarada panóplia de mistificações postas em circulação, a Universidade coopera na instauração de um clima de servidão. Em consequência, ela tem vindo a desfazer-se, paulatinamente, da matriz identitária, a perder o crédito de instituição humana e socialmente relevante. O seu código genético vem sendo desativado e substituído por um programa espúrio e alheio, concordante com o radicalismo neoliberal e o credo do 'utilitês'. O ócio, o fermento criacionista da ciência e da cultura, foi atirado para o caixote do lixo.

Não está a Universidade presa nas malhas do utilitarismo? Qual destas dimensões - ócio criativo ou utilitarismo - está a ganhar a palma olímpica? Como é possível cair no logro da 'empregabilidade' dos cursos, sabendo que uma grande parte dos empregos a desempenhar pelos alunos, hoje no ensino secundário, ainda não está criada? ${ }^{8}$

Estiquemos a corda um pouco mais. A tecnologia devia servir para terminar com a besta humana, para lhe reduzir a carga e o tempo de trabalho. Mas, ao invés, está a aumentar o horário laboral e a contribuir, deste jeito, para con-

8 Uma genuína formação para o exercício profissional não pode descurar qualidades que perfazem o cerne da personalidade, nomeadamente a autoconfiança, a criatividade, a competência argumentativa, comunicativa, discursiva e reflexiva, bem como as dimensões axiológicas exigidas a um cidadão decente. 
denar muita gente ao desemprego. Como se comporta a Universidade neste capítulo? Que partido toma? Que exemplos e influências edificantes irradia para as outras instituições sociais?

\section{II}

As Universidades estão a funcionar e moldar-se segundo valores muito distantes e até contraditórios daqueles que presidiram à sua criação - e ainda hoje são afirmados com pompa e circunstância, porém sem correspondência na sua orientação atual.

A Universidade deixou de ser uma instituição de estudo e formação e passou a ser uma empresa 'educacional', cujo fim é gerar utilidades.

Bolonha é um símbolo da mercantilização do ensino superior, que proletariza os docentes e os futuros profissionais. O mercado não quer pessoas que questionem, mas apenas que vendam os seus serviços e consumam outros. $\mathrm{O}$ 'Processo de Bolonha' faz-lhe a vontade.

Ademais, no modelo de universidade-empresa há que subir o preço da venda do serviço e baixar o seu custo. Vivemos o desencanto e a insatisfação perante um mundo (e uma universidade) que já não oferece nada; só vende.

A formação genuinamente 'superior' hoje está moribunda, porquanto a Universidade se subjugou aos interesses ultraliberais e à lógica do mercado, com perda da sua visão humanista, da reflexão filosófica e da autonomia. O pensamento está sendo triturado e abolido.

Perturbada pela vertigem dos rankings, a Universidade desconsidera o balanço crítico e insuspeito da UNESCO (2013), contido num extenso documento (cerca de 200 páginas). Este adverte para os prejuízos resultantes dos seus usos e abusos e das suas doentias unilateralidades, levando as Universidades a aderir a visões simplistas e a abandonar dimensões essenciais. Os rankings têm que ser vistos como o sal na comida.

A necessidade de formar mestres e doutores, aptos a conhecer e refletir acerca do seu mundo e da sua função, não pode ser subestimada. Isto implica o entendimento de que a sinceridade, a franqueza, a generosidade, o apego à verdade, à firmeza e ao empenhamento na defesa das causas da Humanidade são grandes virtudes humanas, necessárias a um académico e imprescindíveis num professor.

Obviamente os discursos e documentos universitários estão grávidos de princípios que enfatizam a importância da cultura, da ética, da estética, do humanismo e dos valores sociais de pendor positivo. Mas eles pairam no plano 
do abstrato e não conhecem o terreno da concretização. O panorama universitário corre o risco de prefigurar um vácuo ético, não olhando a meios para atingir fins, imitando um elefante a passar numa loja de porcelanas; vai ficando vazio de valores positivos e cheio de indiferença e até valores negativos. Ele não demonstra uma apurada consciência da dimensão não sensível ou insensibilidade para que o homem contemporâneo resvalou.

Por exemplo, nos cursos de doutorado não se descortina a preocupação da formação pedagógica, cultural e humanista, ou seja, atenta-se pouco nas responsabilidades que os doutorandos terão no futuro como docentes. Eles são 'ensinados' a desvalorizar o ensino, são pressionados a finalizar a sua dissertação e dar apoio aos projetos dos seus orientadores. Mais, os doutores são 'formados' para produzir artigos (papers), a valorizar mais estes do que a docência, condicionados para aderirem ao 'overwork', induzidos a praticar uma competitividade destrutiva, arrasadora do outro e redutora deste à condição de lixo descartável. ${ }^{9}$

\section{III}

A obrigação de produtividade da Universidade e dos académicos não pode ser confundida com a mentalidade fabricadora, tecnicista e utilitarista que olha para todas as coisas como objetos de consumo e encara o homem apenas como homo eficiens, homo faber e animal laborans, transformando os meios em fins. Esta mentalidade oblitera a capacidade de pensar, de agir e julgar, bem como de remeter as coisas à sua singularidade e ao seu devido lugar. Ao reificar o homem e exaltar uma racionalidade centrada no critério da eficiência, ela cai num totalitarismo ideológico.

Esta orientação vive de cama e mesa com o homo consumens, atreito ao consumismo de objetos muitas vezes inúteis ou supérfluos, impostos pela moda e pela publicidade. A deriva, hoje em alta, tem um fito claro: esvaziar a vida interior do indivíduo:

de inquietações sociais, espirituais ou simplesmente humanas, isolando-o e destruindo a sua consciência dos outros, da sua classe e de si mesmo. Gerando, assim, a alienação - a ilusão da mentira convertida em verdade (VARGAS LLOSA, 2012, p. 21-22).

9 À insana competitividade, inerente à tresloucada 'papermania', oferece-se opor este conselho de Vergílio Ferreira (1916-1996): "Se és artista, não fales em ser maior ou menor, para não confundires a tua obra com uma prova de atletismo." Quem diz artista, diz investigador, professor, educador... 
Mais, quando se diz que vivemos numa sociedade de consumo, não se olvida que os seres humanos, desde tempos imemoriais, são consumidores. $\mathrm{O}$ que se pretende é, sim, enfatizar a diferença de prioridades entre a sociedade de produtores - a da era moderna e industrial que nos precedeu, orientada pela norma de formar a vontade e a capacidade de produzir - e a sociedade atual, cuja norma é a de moldar os seus membros para, acima de tudo, cumprirem o papel de consumidores seduzidos pela busca compulsiva e incessante de atrações e desejos sempre novos, por nunca estarem satisfeitos de todo ${ }^{10}$.

Que conceitos e noções de Formação (Bildung) e educação, de Homem, de Sociedade e Universidade são transmitidos aos estudantes? Que grau de inquietude ética perante o rumo deste mundo é fomentado? Que apego à cultura e à filosofia é cultivado na maioria dos cursos de pós-graduação?

“A reflexão moral não é apenas um tema especializado, [...], mas parte essencial de qualquer educação digna desse nome." Mais, Os ganhos da ciência estão disponíveis para quem os queira utilizar. Basta consultar as bases de dados! Porém os da cultura, filosofia e ética carecem de ser objeto de aturada meditação e continuada apropriação por cada um (SAVATER, 1993, p. 11).

Que tipo de quadro está a Universidade a formar? Não está a 'funcionalizar' os alunos, tornando-os obesos em conhecimentos superficiais e cegos de visões abrangentes e aprofundadas?

Que preocupação tem hoje a Universidade com a cultura? Continua compromissada com esta ou tem vindo a resvalar para a 'civilização do espetáculo'?

Perante o rolo compressor da globalização e o alastramento da onda do relativismo cultural e de todas as sequelas do elitismo invertido que lhe está associado - o culto e a adulação do grotesco, do boçal, do popularucho, do bacoco, do fácil, do ordinário, do reles e inestético, o avanço e predomínio da ética light ou indolor, do relaxamento e do abaixamento normativo - é fulcral preservar, num nível superior, a norma social, a cultura, a técnica e a linguagem, por serem baluartes de defesa e preservação da liberdade.

\section{IV}

João Ubaldo Ribeiro é perentório:

A norma culta, a dominante, a que é ensinada como correta, [...] é necessária para preservar e aprimorar a precisão da linguagem científica e filosófica, para refinar a linguagem emocional e descritiva,

10 Aconselha-se a leitura de várias obras de Zygmunt Bauman, consagradas à atual era de consumo e de consumidores. 
para conservar a índole da língua, sua identidade e, consequentemente, sua originalidade. Ao contrário do que entendi de certas opiniões que li sobre o assunto, a norma culta não tem nada de elitista, é ou devia ser patrimônio e orgulho comuns a todos. Elitismo é deixá-la ao alcance de poucos, como tem sido nossa política (2011). ${ }^{11}$

Quantos livros de cultura geral lê um estudante de doutoramento durante a trajetória da sua qualificação? Será que lê algum? Não é verdade que a filosofia é vista, em muitos laboratórios científicos, como um vírus que urge defenestrar com ruído e fogo como as pragas na idade média? ${ }^{12}$

Em várias das suas obras, Ortega y Gasset pincela a missão da Universidade. Ela tem que formar pessoas, que se meçam e sobreponham ao seu tempo, com um sistema de ideias vivas que represente o nível cimeiro de desafios, anseios e ideais próprios de cada era. Incumbe-lhe formar quadros autenticamente 'superiores', isto é, dotados de uma força espiritual, reformadora da vida coletiva e individual, oposta à arrogância e aos poderes da frivolidade, insinceridade, estupidez, mesquinhez e irracionalidade. Clarividentes, ilustrados e iluminados para exceder a banalidade e vulgaridade, e para esclarecer os fenómenos e as coisas; capazes de pôr a nu as diversas formas de hemiplegia espiritual e moral; aptos a inteligir e situar a sua especialidade no contexto geral; disponíveis para viver a sua inteligência e entender a vida, a partir da faculdade maravilhosa que é a de perceber a própria limitação.

A isto chama-se 'cultura'. Ela é uma obrigação da Universidade. E é ainda maior a sua obrigação de formar nos estudantes a consciência de que a cultura é uma necessidade imprescindível de toda a vida, é um fator constitutivo da existência, como as mãos, as pernas e os restantes órgãos e próteses que são um atributo e auxílio dos humanos. Como pode a cultura ser descurada na formação universitária? ${ }^{13}$

Necessitamos, certamente, de progresso científico e tecnológico; mas não é inferior a precisão de progresso cívico, estético, ético e moral.

O século XX e o descoroçoador começo do século XXI mostram sobejamente que, a par das liberdades e dos espetaculares avanços na ciência e na

11 Com esta citação pretendemos homenagear o insigne autor de Viva o povo brasileiro, falecido no dia 18 de julho de 2014.

12 Miguel Torga (1943, p. 43) tem carradas de razão: "O homem que o nosso século pede não é o que lê, o que se aprofunda a cavar em si. É um ser biológico perfeito, no sentido corpóreo e psíquico de uma abelha.

13 A título de exemplo, referem-se as seguintes obras de José Ortega y Gasset:

- O que é a filosofia. Lisboa: Edições Cotovia, 1995.

- A Missão da Universidade. Rio de Janeiro: EDUERJ - Editora da Universidade do Estado do Rio de Janeiro, 1999. 
técnica, pode perder-se o sentido dos limites e colocar a Humanidade perante o abismo do mal absoluto. Está em perda o que, em última análise, constitui a base de tudo: a capacidade de distinguir o bem do mal e de fazer a escolha correspondente. Logo impõe-se o regresso aos princípios da ética, da estética, da busca das fontes do sentido da vida, do imaterial e do intangível. Constitui isto uma preocupação central na formação universitária? ${ }^{14}$

O que fazemos com as palavras, as atitudes, os atos e gestos resulta de uma escolha e esta é uma decisão da ética. É nestas decisões que percebemos bem a diferença entre ser mortal e imortal. Quem não dá importância às suas escolhas também não valoriza a sua mortalidade; age como se fosse imortal. Para os imortais é indiferente fazer escolhas, pois eles têm todo o tempo do mundo para fazer o que lhes apetecer.

As nossas escolhas, ou seja, a nossa ética é importante precisamente porque somos mortais, porque vamos morrer, porque nos 'interessa' fazer coisas belas, elevadas e relevantes, enquanto não morremos.

Percebe-se bem o grau de íntimo parentesco entre a formação, a ética e a estética. Ela é uma educação ética e estética da conduta, das forças, dos impulsos e instintos, das paixões e pulsões do ser e estar. Que correspondência encontra este entendimento na preparação dos académicos, nomeadamente dos mestres e doutores?

Será que os orientadores de mestrandos e doutorandos estão despertos e têm tempo para reparar nestas pequenas grandes e imprescindíveis 'coisas'? Com efeito, eles são confrontados com exigências e pressões para orientar cada vez mais estudantes, o que se traduz numa queda da qualidade da orientação e da formação.

O que é feito da 'harmonia' de teoria e prática, de ensino, investigação e extensão, da publicação de artigos para afirmação junto dos pares e da publicação de textos para alimentar e fomentar as necessidades de reflexão e evolução do pensamento e ação dos grupos sócio-profissionais, dos que não são cientistas nem teóricos?

Hoje a carreira académica e a investigação reveem-se no quê: numa competição construtiva ou numa mentalidade destrutiva, desejosa de eliminar os concorrentes e aniquilar os frágeis?

14 A cultura e a identidade do Ocidente nasceram do encontro entre Jerusalém, Atenas e Roma: a fé no Deus de Israel, a razão filosófica dos gregos e o pensamento jurídico dos romanos, passando pelo crivo das Luzes do Humanismo e Iluminismo e convergindo na Declaração Universal dos Direitos do Homem de 1948. Há alguma noção disto nos corredores, nos laboratórios e até em muitas salas de aula das Universidades? 
Albert Einstein (1879-1955) pôs o dedo na ferida: "Não basta preparar o homem para o domínio de uma especialidade qualquer. Passará a ser então uma espécie de máquina utilizável, mas não uma personalidade perfeita" $(1981, \text { p. 16) })^{15}$

Tudo se conjuga para justificar o título O Imbecil Especializado’ que Domenico de Masi deu ao segundo capítulo do seu livro O Ócio Criativo. E para tornar apropriadíssima ao panorama universitário dos nossos dias a sátira que Ortega y Gasset (1883-1955) disparou ao da sua época: "Foi preciso esperar até o começo do século XX para se presenciar um espetáculo incrível: o da peculiaríssima brutalidade e agressiva estupidez com que se comporta um homem quando sabe muito de uma coisa e ignora todas as demais." Ou estoutra:

Dantes os homens podiam facilmente dividir-se em ignorantes e sábios, em mais ou menos sábios ou mais ou menos ignorantes. Mas o especialista não pode ser subsumido por nenhuma destas duas categorias. Não é um sábio porque ignora formalmente tudo quanto não entre na sua especialidade: mas também não é um ignorante porque [...] conhece muito bem a pequeníssima parcela do universo em que trabalha. Teremos de dizer que é um sábio-ignorante - coisa extremamente grave, pois significa que é um senhor que se comportará em todas as questões que ignora, não como um ignorante, mas com toda a petulância de quem, na sua especialidade, é um sábio. ${ }^{16}$

Tudo isto nos intima a revisitar e trazer a cena a missão da Universidade e as teses de Ortega y Gasset. Elas conduzem-nos ao reconhecimento da extraordinária importância e da função séria das atividades ociosas e lúdicas, visando promover o "homem luxoso e desportivo", face ao "homem utilitário e biológico".

Tais atividades são promotoras de felicidade para quem as exercita; elas não estão vinculadas ao imediatismo utilitário. Mais, o desinteresse pelo utilitário e pelo imprescindível impregna o indivíduo de um dom de generosidade que floresce apenas nos cumes de maior altitude vital!

Disse taxativamente o mestre:

15 A passagem está assim grafada neste livro: "Não basta ensinar ao homem uma especialidade. Porque se tornará assim uma máquina utilizável, mas não uma personalidade." Eu modifiquei-a ligeiramente, em função de versões constantes noutros textos, mas sem alterar o seu teor.

16 Não me é possível precisar, com inteiro rigor, a fonte destas citações. Cuidamos que ela pode ser o livro Missão da Universidade. $\mathrm{O}$ facto de esta publicação ter sumido do acervo bibliográfico à nossa disposição não nos permite fornecer ao leitor a informação a que ele tem direito. Fica aqui o pedido de desculpa. Todavia, estas citações encontram-se em textos colocados nas redes e espaços informáticos. 
Os atos utilitários e adaptativos, tudo o que é reação a prementes necessidades, são vida secundária. A utilidade não cria, não inventa, simplesmente aproveita e estabiliza o que sem ela foi criado [...] A vida foi primeiro uma invenção pródiga de possibilidades e depois uma seleção [...] Esta abundância de possibilidades é o sintoma mais característico de vida pujante; tal como o utilitarismo, ao ater-se ao estritamente necessário, à maneira do enfermo que poupa movimentos, é o sintoma de debilidade e vida minguante (ORTEGA Y GASSET, 2011, p. 13-16).

Esta valoração vai ao encontro das posições de Aristóteles e Zygmunt Baumam, já atrás enunciadas. Sintoniza-se com a de Alexandre Koyré (18921964): "Não é do trabalho que nasce a civilização: ela nasce do tempo livre e do jogo." E também com a do escritor francês Théophile Gautier (1811-1872), que resume a noção partilhada por vários pensadores: "Só é realmente belo aquilo que não serve para nada; tudo quanto é útil é feio". ${ }^{17}$

Até hoje estas teses não foram rebatidas. Por conseguinte é imperativo integrá-las no entendimento e organização da vida, da educação, da sociedade e da Universidade.

Precisamos de 'inutensílios', de coisas não 'utilitárias' e do ócio recriador, para aliviar o sufoco do utilitarismo. Que avaliação faz de si a Universidade a este respeito? Ainda é o lugar, por excelência, segundo Romano Guardini (1885-1968), onde se procura a verdade, apenas por ser verdade? Que juízo tecem acerca disto os académicos? Sentem-se bem com a 'forma' da Universidade?

Estamos disponíveis para passar do desassossego à ação, para remir, no discurso e na prática, os lemas comuns, matriciais e originais da Universidade? Aonde transporta este ato de compromisso?

À inquietude pessoana de inquirir associo a franqueza do Padre António Vieira (1608-1697) para concluir:

Tenho acabado, senhores [...] Se a alguém pareceu que me atrevi a dizer o que fora mais reverência calar, respondo com Santo Hilário: Quae loqui non audemus, silere non possumus: O que se não pode calar com boa consciência, ainda que seja com repugnância, é força que se diga.

17 A fonte da primeira citação é a obra de Domenico de Masi (2000). O segundo depoimento é retirado de uma agenda anual, com citações em cada página. Também se encontra em várias plataformas informáticas. 


\section{FIM DO DIA E DA NOITE}

Nunca choraremos bastante quando vemos / O gesto criador ser impedido. (Sophia de Mello Breyner Andresen. Pranto pelo dia de hoje).

Lancemos um olhar profundamente inquieto sobre o tipo de vida que, pouco a pouco, se vai instalando ao nosso redor.

O silêncio da reflexão permite escutar nitidamente o ruidoso e grotesco alarido que lavra no mundo e na Universidade. Um alarido estranho, porquanto resulta do silenciamento da palavra, do seu desvirtuamento, condicionamento e aprisionamento. Meticulosamente estão a ser abatidas a capacidade e sensibilidade para antever e dizer, categorizar e classificar, ordenar e hierarquizar. Há que silenciar os falantes e igualizar os diversos significantes.

É a palavra quem nomeia, separa e diferencia a noite do dia, a claridade da escuridão, a natureza da cultura, o bem do mal, a animalidade da civilidade, a imoralidade da moral, a cegueira dos instintos e paixões da iluminação ética, a grosseria da educação estética, a inteligência da estupidez, o saber da ignorância, a altura da baixeza, a grandeza da vileza, a mentira da verdade, a elegância da obscenidade, a beleza da feiura, a elevação da rasura, a virtude da falta dela.

Mas essa diferença não interessa mais; não é conveniente estabelecê-la e, muito menos, dizê-la. Há um investimento paulatino e objetivo no desencorajamento da palavra, na desconsideração da importância de aprender a palavra diferenciadora e catalogadora. Sem ela é tudo igual, uniforme, monocromático; não vigoram mais as classificações, distinções, diferenças e hierarquias de valor e anti-valor. As trevas povoam o dia e este é feito de luz artificial. O que é uma vantagem, por habituar a viver na neblina e no lusco-fusco como estádio intermédio a caminho do regresso ao ponto de partida: à caverna sombria da desumanidade.

A palavra está a ponto de secar. Nas diferentes corporações e profissões há uma ameaça latente aos que persistem em não a descurar, em cultivá-la e erguê-la. O intuito é de os isolar e levar à exaustão. Custe o que custar, têm que deixar de falar, isto é, de diferenciar e estabelecer fronteiras. A noite e o dia têm que ser em tudo afins. Temos que nos conformar à indiferenciação, aos olhos secos, à alma seca, à secura da imaginação e razão, à secura da degradação e solidão, à secura do abandono de sonhos e ideais, de alternativas e opções, de princípios e normas, de causas e sentidos de transcendência e salvação. 
O ruído que se ouve é o do avanço agressivo do deserto por nós adentro, destruindo cada vez mais a espiritualidade, reduzindo a pessoa a uma coisa, enforcando a ética e calando as bocas que por ela ainda clamam. Não há mais noite, nem escuridão, nem medo do papão. Tudo virou dia. É isso que alumia o tempo atual. É esta a nova medida da felicidade. Já que ela não é possível para a maioria, então que seja vivida intensa e desbragadamente por uma escassa minoria. É este o teor do brilho e do esplendor deste tempo sem dia e sem noite, sem tudo aquilo que esta metáfora encerra.

Em todos os sectores, com a 'nova', 'aberta' e 'atrativa' Universidade à cabeça, é premiada a incompetência para escolher e optar: em todos, sem exceção, é decretada a abolição da separação e valorização, da diferença e vivência do dia e da noite. Não se nota mais se é claro ou escuro todo o tempo. Tanto faz; não gastemos energia inglória a procurar distinguir o que é igual. Habituemo-nos a não afirmar, a bem ou a mal, por decisão própria ou à força da imposição. Não custa nada; a renúncia ao direito e ao dever da palavra liberta do esforço e incómodo de diferenciar e nomear. Usufruamos a condição de mudos e surdos, de acocorados e invisuais. Amordacemos a palavra e acorrentemos a teimosia de a invocar e exercitar. Esqueçamos o mandamento, já velho e gasto, da indignação, do testemunho e protesto. Acomodemo-nos e calemo-nos, indiferentes e obedientes, conformados e contentes. Calada a boca, calar-se-á também o mundo. Imperarão então o marasmo e o pasmo, a quietude e o sossego do silêncio. Nada nos surpreenderá e chocará. O que mais poderemos desejar?!

\section{DAS MENTIRAS DO REFORMISMO NEOLIBERAL EM CURSO}

Quando pratico o bem, sinto-me bem; quando pratico o mal, sinto-me mal. Eis a minha religião. (Abraham Lincoln, 1809-1885).

\section{I}

Na cartilha do ímpeto destrutivo-reformista em vigor há termos como: criatividade, flexibilidade, adaptabilidade, abertura, mudanças fraturantes, etc. Estas palavras enlevam, mas camuflam as suas genuínas intenções. Convidam a aderir ao veloz e voraz e rejeitar o estável e durável, a apreciar o frenesim e desdenhar da serenidade, a optar por ligações e compromissos frouxos e ligeiros que a toda a hora possam ser abandonados. Rebaixam a defeitos e 
fatores de prejuízo os saberes sólidos, o vínculo e a fidelidade ao profundo e consistente, as atitudes e atos louváveis, as habilidades e virtudes confiáveis. E promovem a mais-valias e requisitos desta hora a disposição para destruir o que está feito e quem o fez, o apego ao volátil e superficial, ao movediço e postiço, às aparências e simulações, ao efémero e supérfluo, ao instantâneo e fugaz, ao plástico e reciclado (BENTO, 2012).

Isto fecunda o aparecimento de um novo e intrigante modelo de homem: o homo eligens. Este não é aquele que tem competência e clarividência para discernir, optar e escolher, nem muito menos aquele que escolheu e assume convictamente as suas preferências, mas sim aquele que, a toda a hora, muda de poiso, de sítio e posição, de padrões e referências. Aquele que procura incessante, reiniciada e fracassadamente - e sem manual de instrução! - a montagem e consolidação da incerta, fluida e transitória identidade social, cultural e até sexual, abanado e levado pelas brisas do marketing e do mercado. Porque estar fixo, conservar afinidades e lealdades e ser identificado com estruturas e entidades que zurzem na realidade deste mundo é algo cada vez mais malvisto e é fonte de ridicularização e ansiedade.

Falta criar uma designação mais apropriada para designar este modelo de homem que, além de passar de produtor a consumidor, parece ter necessidade e prazer em se despir de qualidades e desprender de vínculos e compromissos, tradicionalmente aceites e valorizados. Ele exibe, como um troféu, a propensão para flutuar de convicções e opiniões, prescindir de princípios e visões, boiar embalado pelos ventos da moda e pela correnteza do oportunismo e das conveniências, confiar na desordem e espontaneidade, aceitar como inevitável a desagregação da sociedade e das suas instituições, encarar a novidade como progresso, a precariedade como valor, a instabilidade como imperativo, o hibridismo como identidade (BAUMAN, 2007, p. 47).

A charlatanice, a lábia e a léria, a esperteza e a pouca vergonha, a leviandade e a falta de escrúpulos, a mentira e a fraude estão no seu apogeu, gozam de boa saúde e navegam a toda a brida com forte vento pela popa. Ao invés, a seriedade e solidez, a probidade e a honra, o aprumo e a verticalidade, enfrentam ventos adversos, vagas poderosas e uma chuva fustigante. É isto que divide e fratura o mundo; o resto são paliativos para encobrir os despautérios e fugir à prestação de contas à justiça de Deus e dos homens. Não se trata de levantar suspeitas infundadas; mas sim de afirmar que se esgotaram as razões para suportar abusos de confiança e desilusões continuadas. 


\section{II}

Por mais que se procure nas praças e feiras da nossa vida pública - de candeia acesa, como Diógenes, o cínico, (404-323 a.C.) - o esforço é inglório. Vão-se apagando os sinais convincentes da existência abundante de Homens com apego à observância do senso de consciência ética e responsabilidade social. E tudo isto perante uma passividade mortal. Porquê? Porque aumentam os indivíduos ignaros de uma formação enraizada no aperfeiçoamento, na autonomia e coragem morais. Foram conformados e adaptados aos ditames, métodos e apetites da conjuntura, habilitados a sobreviver e a calar os excessos dos que crescem e medram nesta nebulosa caótica.

Afinal é tudo lógico e coerente na implementação do Processo de Bolonha, posta em cena. Não se pode esperar outra coisa de um negócio, em muitos casos, desonesto de cursos de baixo nível e cotação, enganosos e inúteis, que nada oferecem de essencial para a melhoria cívica dos frequentadores, bem como para a contestação e transformação da ordem vigente. É por isso que tais cursos - elaborados e voltados não para qualificar, mas para formatar e explorar cidadãos - são facilmente vendidos e, por vergonha ou incapacidade ou por ambas as coisas, dificilmente desmascarados pelos aliciados e ludibriados (BAUMAN, 2007, p. 21).

Admiremos, pois, os sucessos garantidos pelo tsunami da demagogia e facilidade: certificados de destruição de utopias e ideais, produção em série de identidades com duradoira infantilidade, de especialistas sem espírito e de indigentes culturais, metidos entre palas e varais, presos ao vazio e alienação do presente, sem inquietação e noções para o futuro. Eles podem vir a conhecer alguns sucessos materiais, mas dificilmente escaparão à companhia permanente da pobreza, do fastio e cansaço espirituais.

Ora isto manda perguntar. Serão viáveis a democracia, a liberdade e a Universidade, sem elites intelectuais, científicas e outras, sem Homens Públicos com nobreza e honradez de carácter, transparentes e confiáveis, à altura dos desafios? Onde estão os portadores do fulgor da honestidade, da retidão e decência, capazes de iluminar com esse clarão os caminhos deste tempo de dúvida e escuridão? Se ainda existem, então tirem a máscara e façam o favor de se mostrar; é chegada a sua hora!

\section{PALAVRAS EXIGIDAS E PREFERIDAS}

Pensai como homens de ação, atuai como homens pensantes.(Thomas Mann, 1875-1955). 
Dizem-me que as minhas palavras têm a forma de pedras aguçadas. E advertem-me de que elas comportam sérios riscos. Eu agradeço o aviso e reparo. Mas não consigo calar-me e fechar os olhos à desvergonha e ao cinismo das circunstâncias. Como a carapaça agarrada à tartaruga, trago comigo a condição e a sina de usar termos à medida do contexto.

Assim gosto de evocar o mérito, o suor, o empenho e dignidade. Amo o jogo limpo e detesto a batota; aprecio a política (entendida como cuidado da polis, da cidade e da comunidade) e abomino a farsa. Subscrevo a definição de 'trabalho' que vem nos dicionários económicos: "esforço individual ou coletivo destinado a produzir um bem ou um serviço." Defendo a 'democracia' por me lembrar que ela e o Estado existem por causa das pessoas, que estas são anteriores e criaram aqueles para o seu serviço e dignificação.

Por isso recuso a corrupção, mas adiro à sua definição, elaborada pelo velho e sempre atual Aristóteles (384-322 a.C.): "alteração do estado das coisas, modificação e desvio de conteúdo, originando o desvirtuamento do homem." E também louvo a definição registada nos dicionários da nossa língua: "ato de apodrecer, de estragar ou desnaturar." O leitor por certo partilha o meu gosto e está farto de tapar o nariz ao intenso fedor que lavra no mundo.

Portanto gosto de palavras que nos incitem a repudiar a corrupção, a tomar a decisão de não permitirmos que ela faça parte do dia-a-dia, de não cairmos na indiferença, resignação, negligência e permissividade. Para não ficarmos podres, desvirtuados, desnaturados, putrefactos, nauseabundos. Eis porque aplaudo atitudes, medidas e palavras que combatam a fraude, o contrabando de influências, a promiscuidade, a hipocrisia, o servilismo, o lambe-botismo, o conúbio das oligarquias que medram com a pobreza e o sofrimento.

Nós somos criação de palavras e frases, até porque "no princípio era o verbo". Escolhamos, pois, as que criam o nosso bom-nome, elevação e honorabilidade. E atuemos de acordo com elas. Avivemos a inquietude, o alerta constante e a interrogação pronta. Alijemos o insuportável peso da despergunta que é timbre de acuados e medrosos, de bajuladores e outros infra-humanos.

Aqui e agora, obriguemo-nos a usar palavras cortantes como pedaços de vidro. As que expõem a revolta que nos consome, as traições que contra nós cometem, as mentiras, falsidades e petas que nos vendem, as farsas que para nós representam, a poeira suja que nos atiram aos olhos. As que discordam, porque o facto de todos estarem de acordo não transforma o falso em verdadeiro. Ademais, a sabedoria desalinha e tende a provocar discórdia; unânime é quase sempre a ignorância. Não há bom senso nas maiorias; caso contrário, 
teriam razão os milhões de moscas que poisam e vegetam em tudo quanto é dejeto e trampa.

Porque as palavras expressam o que ainda não somos ou não temos, deitemos fora as que ignoram as coisas elevadas e afundam no abismo e perda. Apeguemo-nos às que fazem sol de noite, acendem fogueiras na água, pintam de cores o orvalho, criam plantas no deserto. Como Manoel de Barros, o insigne mestre do Pantanal brasileiro, digamos palavras que quebrem o silêncio dos ofendidos, falem por eles, sejam os seus olhos, ergam o chão até ao apogeu infinito e deste façam matéria de ensino. São essas as da competência mais entendida e sábia em pessoas do que em livros, alicerçadas mais em inutensílios do que no utilitarismo e pragmatismo do quotidiano, mais inclinadas a louvar um poema do que a construção de uma central nuclear.

Ressuscitemos as palavras aladas e verticais. Elas reinventam o melhor que há em nós e se vai apagando e perdendo, por ação do tempo e corrupção dos seus agentes.

Digamos a palavra 'Universidade', como quem reza uma oração e acredita em tudo o que ela encerra!

\section{CONCLUSÃO}

Quem pretende servir os homens tem aí a melhor dádiva a fazer-lhes: a de se manter sem desvio nas épocas piores, quando todos os outros recorreram ao subterfúgio e a todos cegou a mesma escuridão de um mal presente. (Agostinho da Silva, A opinião pura e elevada).

Devemos olhar para o sarcófago como quem contempla um legado repleto de códigos enigmáticos. Ele requer ser aberto e descodificado, porquanto encerra fantasias, símbolos, ideais, ânsias, inquietudes, 'coisas' 'inúteis', por não serem necessárias ao quotidiano, mas das quais não podemos prescindir, por estarem ligadas ao indizível, ao intangível e invisível, ou seja, àquilo que nos atrai para o alto, para a esfera da humanização e divinização, concedendo assim as asas da ilusão - o alimento preferido da felicidade - à precaridade e transitoriedade da nossa existência.

Oxalá a abertura e descodificação do sarcófago nos acordem para a necessidade de remediar o saque que a 'cultura do espetáculo', da banalização, da efemeridade, fragmentação, frivolidade e superficialidade vem provocando nas últimas décadas, em todas as áreas da atividade (artes plásticas, cinema, 
jornalismo, literatura, programas de televisão e mesmo na educação dita superior e universitária). A diversão e o entretenimento são erigidos em valor e bem supremos, com manifesta depreciação da norma culta e da bitola elevada. Pouco a pouco, quase sem darmos conta, a cultura da espiritualidade, da erudição, dos arquétipos de elevada conduta cívica e espiritual, ética e estética vai ficando pelo caminho. Sobrecarregamo-nos de dimensões banais, profanas, efémeras e voláteis; e empobrecemo-nos de referenciais sagrados, divinos, duradoiros e superiores.

\section{II}

Será legítimo considerar que a Universidade hodierna continua a ser um instrumento do processo civilizatório? Continua sendo um polo irradiador de influências positivas, a ponto de ser uma referência de exemplaridade para outras instituições sociais? Que cultura e nível do trato (inter)humano se exercita e atinge nela?

Consegue a Universidade atual escapar aos tentáculos do polvo do mercado e do sistema ideológico que o sustenta ou tornou-se mais um dos seus fieis escudeiros? Ainda é uma acrópole e ágora do livre pensamento ou, ao invés, aderiu acriticamente ao receituário dogmático do neoliberalismo e do managerialismo?

A resposta não é entusiasmante. Os dogmas foram péssimo sustento e ocasionaram o definhamento das religiões e das suas estruturas. A Universidade não aprendeu a lição; deixou-se invadir por eles. Escapa-lhe a leitura e a compreensão das consequências deste alerta do escritor britânico Gilbert Keith Chesterton (1874-1936): "Dogma não significa ausência de pensamento, mas sim o fim do pensamento" (2014).

Isto é deveras trágico. A política está desacreditada em todo o mundo, devido ao facto dos políticos não estarem à altura e se dedicarem à gestão dos interesses pessoais e grupais, tornando-se agentes ou cúmplices da corrupção, em detrimento da defesa e tutela do bem comum. Mas... têm estado à altura os Professores universitários? Se não arrepiar o caminho, que está seguindo, a Universidade terá o mesmo fado e destino.

\section{III}

Reabilitar a imagem e a missão da Universidade e dos seus Professores não é pedir pouco. É pedir muito e só em atitude de humildade pode ser cumprida 
a tarefa. Para tanto, talvez sirva de ajuda a inspiração num alemão muito incomodativo, chamado Kant, já atrás lembrado.

Na sua obra Crítica da Razão Pura, ele reconheceu as dificuldades, as inquietudes, os limites e as impossibilidades da razão humana para dar resposta a todas as questões que lhe são impostas e àquelas que ela própria se coloca a si mesma. Todavia, esta atitude humilde do filósofo não se estribava nem apelava à demissão ou resignação; fundava-se na crítica e exigia a sua aplicação a todas as coisas. Por mais sacrossanta ou majestática que seja qualquer entidade, ela não pode subtrair-se à instância da crítica. A razão humana não concede respeito a nada e ninguém que se exima ao seu exame livre e público. É a crítica que legitima a obra; e esta, por mais que se cuide autotélica e portadora da capacidade única de distinguir os vivos e os mortos, não o será sem se submeter ao cepo do julgamento, do questionamento e da explicação.

Como é sabido, todas as obras, não obstante a sua perfeição, são imperfeitas; nenhuma é incólume. Tudo quanto recusa expor-se à crítica deixa de ser fonte de esperança e transforma-se num poço de alienação, dominação, mistificação, de ilusão inócua, de indiferença, niilismo e vazio.

A humildade do filósofo de Königsberg não o paralisou ou impediu de formular questões fundamentais, sobejamente conhecidas:

- Que posso eu saber?

- Que devo eu fazer?

- O que me é permitido esperar?

Estas três perguntas são fundidas numa quarta, até hoje sem resposta suficiente, que porventura nunca obterá:

- O que é o Homem?

A pergunta é ancestral. Para lhe responder foram elaboradas mitologias e religiões, culturas e civilizações. A mesma via é seguida pela plêiade de pensadores e filósofos da antiguidade, modernidade e atualidade, movidos pela ânsia de alicerçar a dignidade da forma humana do homem. O intento não logrou, por enquanto, realização satisfatória.

A Caixa de Pandora continua aberta. Entre todas as ciências, a da Humanidade e Humanização do homem não é a mais desenvolvida, nem a mais cultivada. Hoje o empreendimento parece até concitar um certo desdém.

Nesta conformidade, que exclamações ou, quiçá, imprecações soltaria, por exemplo, Nicolas Malebranche (1638-1715), padre e filósofo racionalista francês, acérrimo defensor de uma ciência do Homem, se lhe fosse dado 
contemplar o panorama atual da Universidade e dos critérios vigentes nas agências avaliadoras e financiadoras dos docentes universitários, dos projetos e bolsas de pesquisa?

Não andaria longe desta apreciação de Fernando Savater (1997, p. 82):

No campo da educação, um fantasma é o hipotético desaparecimento das humanidades dos planos de estudo, substituídas por especialidades técnicas que mutilarão as gerações futuras da visão histórica, literária e filosófica, imprescindível para o cabal desenvolvimento da plena humanidade $[\ldots]$.

Se a Universidade quer manter a aspiração de sair do sarcófago em que se deixou encerrar, então tem que colocar no centro da sua reflexão a quarta questão kantiana e a preocupação de cooperar na renovação da procura de uma resposta. Porque não é possível uma Humanidade sem Humanidades!

Neste empreendimento não terá, certamente, a companhia de muitas instituições, às quais daria muito jeito queimar o legado de Kant, nomeadamente o da noção de que o ser humano é uma entidade dotada de dignidade, não tem preço, não é mercadoria ou produto descartável. E não pode olvidar, como sublinham tantos pensadores, que o $E u$ só existe na relação com o $T u$, apenas se constrói nos encontros de Um com o Outro. Ou seja, se a Universidade assumir o compromisso de responder à questão ( $O$ que é o Homem?), obriga-se a ir mais longe: tem que se consagrar à Humanidade e dedicar igualmente à configuração de uma sociedade e ágora correspondentes. ${ }^{18}$

\section{III}

Deixemo-nos encorajar pelo conselho de Agostinho da Silva (1906-1994):

A opinião que se emite ou a regra que se estabelece não tem que se importar com as circunstâncias em que se encontram os homens nem com as possibilidades de acolhimento ou recusa que o mun-

18 "Escolher hoje a humanidade - diz Fernando Savater - é optar por um projeto de autolimitação no que se refere ao que podemos fazer, de simpatia solidária perante o sofrimento dos semelhantes e de respeito perante a dimensão não manejável que o humano deve conservar para o humano. [...] Saber-se humano não é aceitar um facto - biológico ou cultural - mas tomar uma decisão e empreender um caminho". Savater recusa "a audácia empreendedora (que tenha) uma barreira para lá da qual só espera o inumano", advoga o respeito pelo "enigma livre do humano, que ninguém pode manejar nem condicionar instrumentalmente" e proclama: "Que o humano reconheça o humano, em parte por natureza e em parte por fraternidade simbólica [...], que o humano procure a humanidade sob a pluralidade das suas manifestações, que os homens cresçam e vivam entre humanos, sempre valiosos uns para os outros..." (SAVATER, 2004, p. 146-148). 
do lhe oferece; o que é hoje grão seco levanta-se amanhã sobre as ondas do campo como a espiga mais alta e mais cheia; o culto da verdade não se compadece com a adoração dos deuses que presidem aos dias nem com a vã agitação que é de regra no formigueiro humano; cada um tomará o que se diz como quiser; a sua atitude, porém, só interessará enquanto fenómeno base para uma nova legalidade. ${ }^{19}$

Com determinação afim, tomemos à letra a prescrição de Miguel Torga (1946, p. 142):

O povo está divorciado da cultura, e encolhe-se cada vez mais na sua fome e na sua ignorância. Somos nós, os que saímos e o queremos verdadeiramente servir, que temos o dever de o procurar, de o esclarecer, de o interessar ativamente na sua própria salvação.

Por outras palavras, a Universidade tem que avocar o princípio da responsabilidade humana e apostar na edificação da Humanidade como fraternidade plural e universal. Tendo presente a conhecida máxima de Ortega y Gasset: Yo soy yo y mi circunstancia, y si no la salvo a ella no me salvo yo.

Esta asserção de Ortega é uma atualização e um eco ou prolongamento da exortação e inquietação que vem do fundo dos tempos e os atravessa, assim expressa no Talmude da Babilónia: Se não respondo por mim, quem responderá por mim? Mas se só respondo por mim, serei ainda eu? ${ }^{20}$

Qual é hoje, afinal, a identidade da Universidade? Que harmonia revela nas diferentes facetas do seu objeto e missão? Como está nela a 'Formação' ou Bildung?

IV

A Universidade deve ser uma 'instituição da Palavra', de palavras que elevem a norma pública. Para isso tem que obviar a perda da sua substância, porquanto a degradação e a banalização da linguagem acarretam o empobrecimento do pensamento, distraem do infinito, impedem-nos de ver a Alma e de

19 Agostinho da Silva, A opinião pura e elevada, in: Literatura contemporânea em língua portuguesa (clube de leitura com autores contemporâneos de língua portuguesa, constituído em 2013 no google).

20 "A sabedoria desta dupla interrogação do Talmude da Babilónia, desde longa data e neste tempo em particular, coloca os seres humanos perante uma proposta ética fundamental. Cada pessoa é chamada a responder por si, sem que ninguém possa substituir-se-lhe na sua intransmissível e inadiável resposta. Mas essa resposta não pode ser dada só por si: implica responsabilidade pelo outro. $\mathrm{O}$ descuido, a distração, a indiferença para com os outros chegam a fazer vacilar a identidade própria: se só respondo por mim, serei ainda eu? [...]. A pessoa humana, ao ser ontologicamente entendida como um 'eu-com-outros-no-mundo' (Merleau-Ponty), requer que a responsabilidade por si se articule com a do próximo. Ou de outro modo: o rosto do outro está sempre diante de mim e exige de mim resposta (Lévinas)" (MAGALHÃES, 2013). 
captar mais leves, palpáveis e tangíveis os fundos e indecifráveis mistérios da vida. Enfim, atiram-nos para o inferno orwelliano.

A palavra universitária, para o ser e honrar a sua génese, tem que procurar avaliar e compreender o universo de facetas que qualquer assunto apresenta. Por isso temos que estruturar o nosso discurso, fazendo-o passar pelo crivo do pensamento contra si mesmo e da preocupação em saber questionar a tese que não defendemos.

Isto obriga-nos a recuperar o primado da liberdade interior e a introduzi-la no processo de elaboração mental e circulação no espaço público, a recusarmos o acomodamento ao conforto paralisante dos estereótipos do senso comum e do linguajar vigente. Só assim daremos um contributo válido para a qualidade da ágora, da polis, da cidade e da democracia.

Ele é deveras requerido, atendendo ao que mais abunda por aí, na televisão, nos jornais, na blogosfera: debilitação do debate, repetição de litanias superficiais, recusa da complexidade, invocação de receitas mágicas, moralismo ingénuo, exibicionismo opinativo sem fundamentação, supressão da crítica exigente e culta, um palrear a raiar os limites da cretinice, infantilização geral da sociedade, fuga à realidade, consumismo de slogans e ideias semelhante ao consumismo de coisas materiais.

Por favor, não ignoremos que a nossa maior obra-prima é viver como deve ser; o resto - cargos, honrarias, publicações, ganhos monetários, etc. - é um simples suporte!

Creio que é deste jeito que a Universidade se poderá levantar do sarcófago e do Leito de Procrustes. O seu corpo e o seu espírito entoarão, de novo em uníssono, esta prece escrita por Pascal Mercier (2008, p. 170):

Não quero viver num mundo sem catedrais. Preciso da sua beleza e da sua transcendência. Preciso delas contra a vulgaridade do mundo [...] Um mundo sem estas coisas seria um mundo no qual eu não gostaria de viver [...] Preciso delas contra o veneno insidioso do superficial e do supérfluo.

\section{REFERÊNCIAS}

BAUMAN, Zygmunt. Vida líquida. Rio de Janeiro: Jorge Zahar, 2007.

BAUMAN, Zygmunt. Danos colaterais: desigualdades sociais numa era global. Rio de Janeiro: Jorge Zahar, 2013. 
BENTO, Jorge Olímpio. Corrida contra o tempo. Posições e intervenções. Belo Horizonte: Edição da Casa da Educação Física; Campinas: Centro de Estudos Avançados da UNICAMP, 2012.

CHERSTERTON, Gilbert Keith. Escrito na Pedra. Jornal Público, 20 jul. 2014.

DOMINGUES, Bento. Santas, submissas e rebeldes. Jornal Público, 03 fev. 2013. p. 53.

EINSTEIN Albert. Como vejo o mundo. 11. ed. Rio de Janeiro: Nova Fronteira, 1981.

LOUREÇO, Eduardo. Egoista, n. 52, p. 11-12. Estoril: Estoril-Sol (III) Turismo, Animação e Jogo.

MAGALHÃES, Isabel Allegro de. Retorno ao futuro. Jornal Público, 14 jan. 2013.

MASI, Domenico de. O ócio criativo. 3. ed. Rio de Janeiro: Sextante, 2000.

MERCIER, Pascal. Comboio nocturno para Lisboa.2. ed. Lisboa:

Publicações Dom Quixote, 2008.

ORTEGA Y GASSET. El origen deportivo del estado. A Coruña: Edición INEF Galicia, Universidade da Corunha, 2011.

RIBEIRO, João Ubaldo. Observações de um usuário. O Estado de S. Paulo, São Paulo, 29 maio 2011.

SAVATER, Fernando. Ética para um jovem. Lisboa: Editorial Presença, 1991/1993.

SAVATER, Fernando. O valor de educar. Lisboa: Edições Presença, 1997.

SAVATER, Fernando. A coragem de escolher. Lisboa: Publicações Dom Quixote, 2004.

SERRES, Michel. Hominescências: o começo de uma outra humanidade. Rio de Janeiro: Bertrand Brasil, 2003.

TORGA, Miguel. Diário II. Coimbra: Edição do autor, 1943. 
TORGA, Miguel. Diário III. Coimbra: Edição do autor, 1946.

UNESCO. Rankings and accountability in higher education. Uses and misuses. Paris: UNESCO Publishing, 2013.

VARGAS LLOSA, Mário. A civilização do espetáculo. Lisboa: Quetzal Editores, 2012.

VIEIRA, António. Sermão do bom ladrão. Proferido em 1655 na Igreja da Misericórdia de Lisboa (Conceição Velha), perante D. João IV e a sua corte. 